\title{
マニラ首都圈における都市化とモータリゼーション の相互作用系の制御に関する分析
}

\author{
土井 健司 ${ }^{1}$ ・紀伊 雅敦 $^{2} \cdot$ 金 広文 $^{3}$ ・シーラ ガーブカヤン ${ }^{4}$ \\ ${ }^{1}$ 正会員 工博 東京工業大学大学院助教授 情報理工学研究科（T152-8552 東京都目黒区大岡山 2-12-1） \\ ${ }^{2}$ 正会員 博 (工) (財)運輸政策機構 運輸政策研究所 研究員（テ105-0001 東京都港区虎/門 3-18-19） \\ ${ }^{3}$ 正会員 博 (工) 日本学術振興会研究員（東京工業大学大学院 情報理工学研究科） \\ 4 学生会員 工修 東京工業大学大学院 情報理工学研究科博士課程
}

\begin{abstract}
本研究では, 途上国大都市の交通問題の所在を経済成長, 都市膨張と自動車依存の相乗作用による負の社 会的影響と位置付けし,この制御に関わる政策評価方法の開発を試みている. まず, 自動車保有への主要な影響 要因が中高所得世帯の郊外立地および土地利用の混在であることを明らかにした上で, 所得階層別の居住立地 とスプロール市街地の形成メカニズムを捉え, 都市化とモータリゼーションの相互作用系をモデル化している. これ を東南アジアで最も梁刻な交通渋滞を抱えるマニラ首都圈に適用し, プライシング・課税等の経済施策, 軌道系交 通整備および多極型都市政策等の効果を, 自動車保有率, 走行量, 大気環境負荷の抑制およびこれらを考慮し た厚生変化により評価している.
\end{abstract}

Key Words: suburbanization, motorization, developing countries, land use analysis

\section{1. はじめに}

途上国大都市においては, 都市交通問題の改善を 図る上でモータリゼーションの適切な制御が急がれる. しかし,この制御の意味あいは,すでに自動車保有率 が飽和に近い先進国での需要管理とは必ずしも同義 ではない. 都市化の初期段階あるいは都市化に先駆 けて軌道系の交通基盤の整備が進められてきた先進 国大都市の状況とは異なり, 途上国大都市ではモータ リゼーションが都市化を加速し, 圧倒的な勢いで都市 圏の膨張が進行している点に特徴がある. 軌道系など の大量輸送機関の供給が都市化の後追いとなり, その 一方で, 中高所得層の増加が自動車依存型の郊外居 住を促す中で, いかに都市化とモータリゼーションの相 乗作用を制御するかが問われる. その際の重要な視点 は, 図一1 に示す都市活動, 土地利用, 自動車交通間 の相互リンケージの把握であろう.

本研究では, 人口が 1 千万人を超えて膨張を続け, かつ人口増加率をはるかに上回る勢いで自動車保有 率が増加を見せるフィリピンのマニラ首都圈を対象とし て, 都市化とモータリゼーションの相互作用系を捉える とともに, 都市・交通政策によるその制御の可能性を分

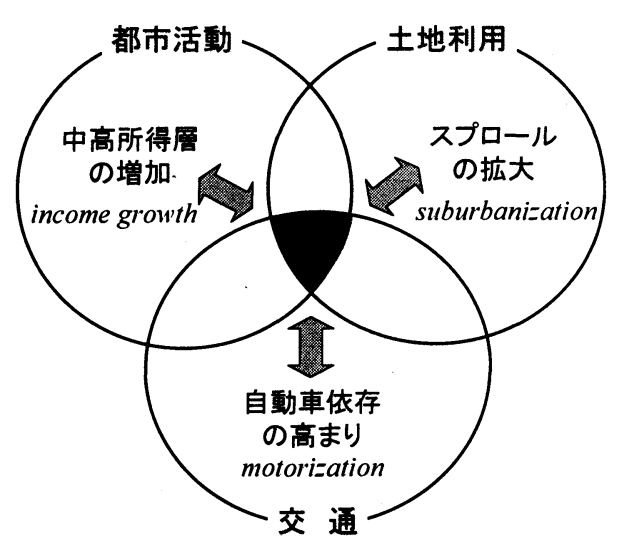

図一1 都市成長とモータリゼーションとの相乗作用

析することを目的としている. 具体的には, 多様な社会 構造や空間構造を有するマニラ首都圈での自動車保 有率への影響要因を抽出した上で, 1)モータリゼーシ ヨンの郊外化への寄与, 2)郊外化に伴うスプロール市 街地の形成等のモデル化を介して, 相互作用系の定 量的把握を試みる. その上で, 自動車交通の抑制に 関わる都市・交通政策の効果を, 交通負荷の抑制, 環 境改善便益および厚生変化という尺度により評価し, 政策の有効性を論じるものである. 


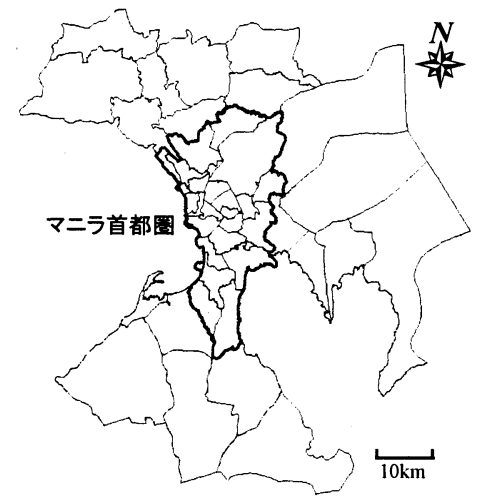

図-2 マニラ首都圏とその後背地域

なお, 関連した先行研究として, 国際比較, 都市間 比較に基づく都市構造と自動車依存との関係分析が 見られる. Kenworthy and Laube ${ }^{1)}$ はアジア途上国を含 む世界46都市におけるデータをべースに, 交通, 土地 利用, 経済要因の関係を分析し, クロスセクションで見 た場合, 経済的要因よりも土地利用要因が自動車依 存と強い関係を持つことを示している. Gakenheimer ${ }^{2)}$ は開発途上国におけるモビリテイ改善に関する論点の 整理を行い, プライシングなどの交通需要管理技術と 計画的な都市開発コントロールの必要性を示唆してい る. 林ら ${ }^{3)-5)}$ はロンドン, 東京, 名古屋, バンコクを対象 として都市化のサイクルを捉えるとともに, 都市圈の広 域化とそれに起因したトリップの長距離化および環境 負荷の増大をマクロに分析している. また, 加藤・林 ${ }^{6)}$ はわが国の 13 の主要都市を対象しして, 交通施設投 資, 都市成長管理政策のシミュレーションを, 1965 95 年の間の多時点で行い, 公共交通整備と, 早期の都 市の高密化政策, 道路整備が交通負荷・エミッションの 削減に効果的であることを示している.これらの研究で は, 自動車依存の構造を, 交通市場の内部要因のみ ならず, 都市の経済活動や土地利用との関係から考察 し, 土地利用と交通との相互作用を踏まえた総合的管 理方策の必要性を指摘している. 土井・紀伊ら ${ }^{71}$ は, マ ニラ首都圈を対象としてモータリゼーションの要因分析 を実施し, 自動車依存が, 高所得世帯の郊外立地と市 街地のスプロール的拡大により促進されることを示唆し， スプロール度, マストラ成立可能性, 自動車依存度とい うつの要素間の因果関係分析を共分散構造モデル により分析している.

途上国を対象としたものではないが，高見・室町ら ${ }^{8)}$ は欧米における土地利用・交通施策に関する議論を 整理し, 都市のコンパクト化による活動機会の近接性 の向上と, 公共交通のサービスレベル改善等による自 動車からの手段転換が自動車利用を削減に有効であ ることを示している。 また, 芦沢 ${ }^{9}$ は我が国の全国の

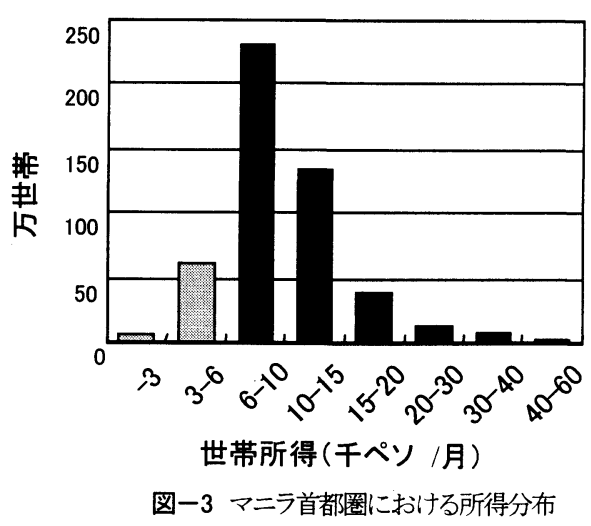

市を対象としたクロスセクション・データに基づき, 自動 車保有率を社会経済要因および都市構造要因を説明 変数として分析し, 後者に関わる人口密度, 市街地形 状等の影響力が高いことを指摘している. 加藤ら ${ }^{10}$ は, 我が国の主要7都市における自動車保有を, 経済成 長レベルと都市構造要因を用いてモデル化し, 都市の 低密度な広域化が潜在的な自動車市場規模を拡大す ることを示している.

また, 青島ら ${ }^{11}$ は郊外居住化とモータリゼーションと の関連性を,前橋・高崎のパーソントリップ調査の結果 から分析している.

本研究は, 途上国大都市におけるモータリゼーショ ンの進展構造を把握する上で, 以上のような比較分析 や事例分析等にとどまらず, モータリゼーションと都市 成長との依存関係を理論的に把握し, システムとして 表現することを試みる.

\section{2. マニラ首都圏における自動車依存構造の 分析}

\section{（1）自動車保有率の影響要因}

既往研究が示すように, 所得要因と自動車保有率と の間には強い関連性があることが, 時系列分析および クロスセクション分析から指摘されている. 図ー3はマニ ラ首都圈における所得分布を示し, また図一4は23の 自治体ごとの平均所得と自動車保有率との関係を見た ものである. また, 世帯を低所得層と中高所得層に分 けた上で, 保有率と中高所得世帯比率との関係を示し たものが図一 5 である. 中高層所得世帯の比率は, い わば中流階層の厚みを表す指標であり,ここでは所得 水準が貧困線 (poverty line) である 6 千 peso/月以下の ものを低所得層, それを超えるものを中高所得層と定 義している. 貧困線以下に位置する低所得世帯の自動車 取得可能性は極めて低いものと考えられる. 両図を比較 


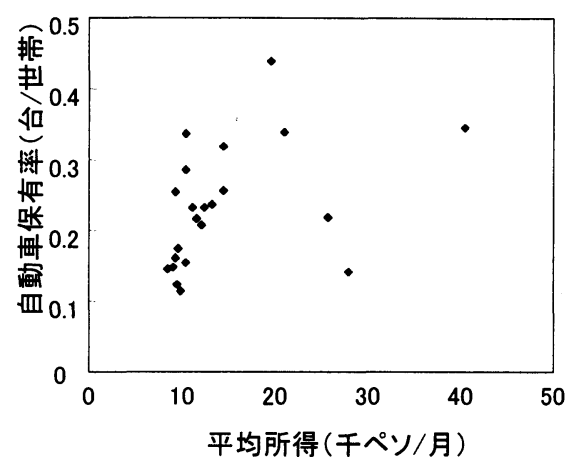

図-4 地域の平均所得と自動車保有率

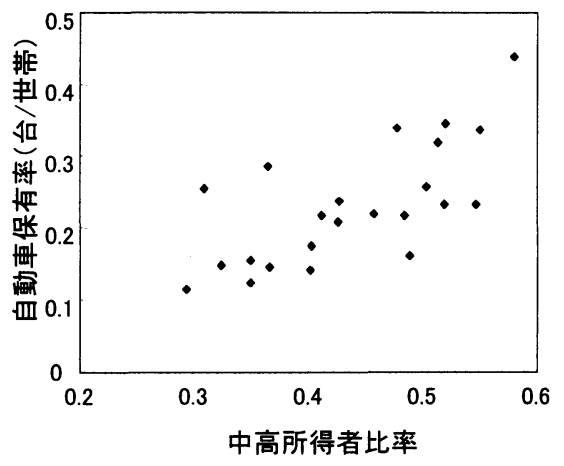

図-5 中高所得者比率と自動車保有率

すると, 図一5においてより強い比例関係が読みとれる が, 所得格差が大きいマニラ首都圈においては平均所得 よりむしろ中高所得者の比率が自動車取得可能性を反映し た指標となっていることがわかる。

自動車保有率に影響を及ぼす都市構造要因として, 多くの既往研究では人口密度が用いられており, 低密 度開発がより高い自動車依存をもたらすことが指摘さ れている. 図一6 はマニラ首都圏における両者の関係 を示したものである. この図からも, 人口密度の低い地 域において自動車保有率が高いとの傾向が読み取れ るが, 2 万人 $/ \mathrm{km}^{2}$ 以下の地域において保有率のばら つきが大きく, 密度の違いからは十分に説明されない.

こうした低密度域での市街地特性の相対的な違いを 表すために, 本研究では, 土地利用状況を表す指標と してジョイン值を導入する. ジョイン值は2種の土地利 用の混在度を, 両者の境界長の和で表現するものであ り, 本研究ではより具体的に, 単位面積内での都市的 土地利用と自然的土地利用との境界長の和と定義す $3^{12)}$. 密度と連担性の観点加市街地形態は表一1の ように分類されるが, 自動車依存度の異なるスプロール 市街地とコンパクト市街地との差違は密度指標のみに よっては峻別されない. 図-7 よりジョイン值は低密度域

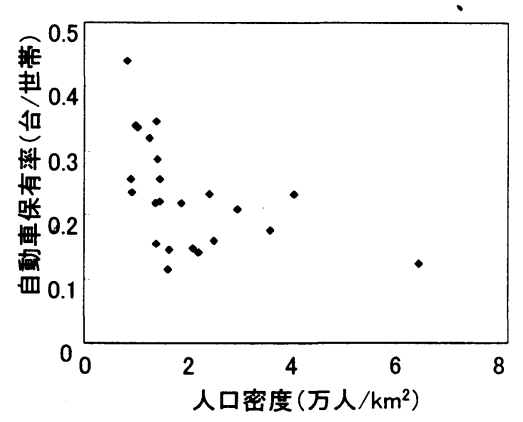

図-6 人口密度と自動車保有率との関係

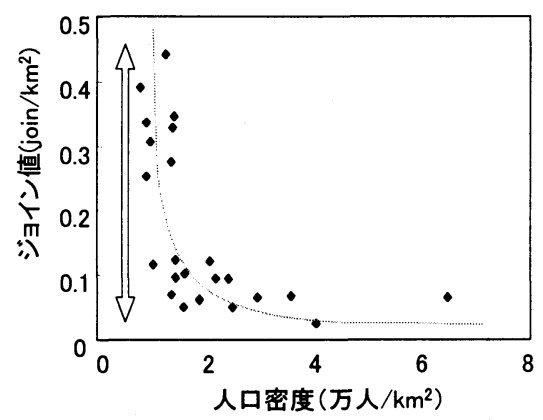

図ー7人口密度とジョイン值との関係

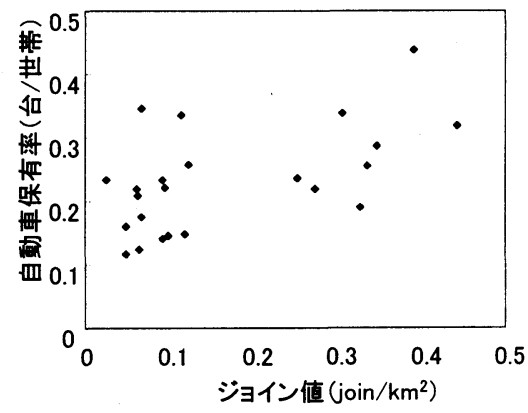

図－8 ジョイン值と自動車保有率との関係

表ー1 市街地形態とジョイン值指標の関係

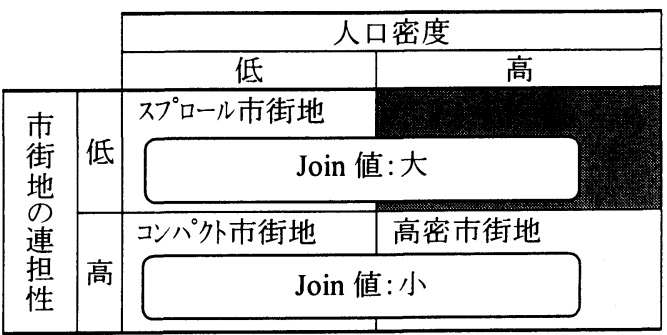

での市街地形態の違いを捉え, また図-8 より, 自動車 保有率との間に比較的高い相関をもつ指標であること が読み取れる.これらのことから, 都市的土地利用と自 

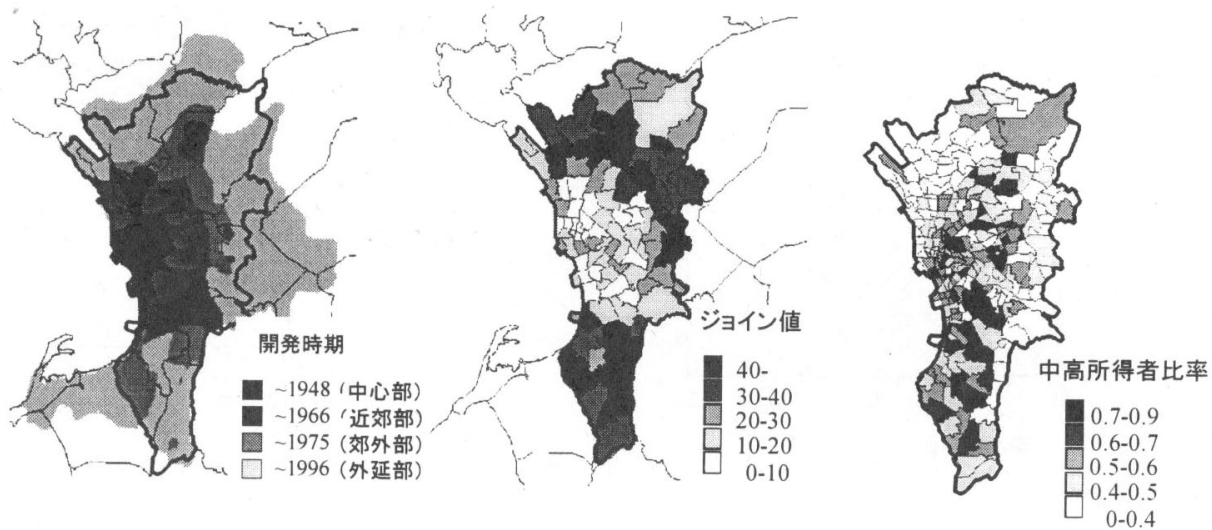

図ー9 マニラ首都圈の郊外化 ${ }^{7)}$, スプロール化および居住立地

表－2 自動車保有モデルの推定結果

\begin{tabular}{|c|c|c|c|c|}
\hline \multicolumn{2}{|c|}{ 説明変数 } & Model-1 & Model-2 & Model-3 \\
\hline \multicolumn{2}{|c|}{ 中高所得世帯比率 } & $\begin{array}{l}0.720 \\
(4.89) \\
\end{array}$ & $\begin{array}{l}0.797 \\
(5.64) \\
\end{array}$ & $\begin{array}{r}0.724 \\
(6.17) \\
\end{array}$ \\
\hline \multirow{3}{*}{$\begin{array}{l}\text { 都 } \\
\text { 市 } \\
\text { 構 } \\
\text { 造 } \\
\text { 要 } \\
\text { 因 }\end{array}$} & $\begin{array}{l}\text { 人口密度 } \\
\left(\text { 人 } \mathrm{km}^{2}\right)\end{array}$ & $\begin{array}{r}-0.810 \\
(-1.68) \\
\end{array}$ & & \\
\hline & エントロピー* & & $\begin{array}{l}0.304 \\
(1.23) \\
\end{array}$ & \\
\hline & $\begin{array}{l}\text { ジョイン値 } \\
\quad\left(\text { join/ } / \mathrm{km}^{2}\right)\end{array}$ & & & $\begin{array}{l}0.301 \\
(3.46) \\
\end{array}$ \\
\hline \multicolumn{2}{|r|}{$\begin{array}{c}\begin{array}{c}\text { 幹線道路密度 } \\
\left(\mathrm{km} / \mathrm{km}^{2}\right)\end{array} \\
\end{array}$} & $\begin{array}{r}-0.0414 \\
(-1.31)\end{array}$ & $\begin{array}{l}-0.0843 \\
(-3.10)\end{array}$ & $\begin{array}{l}-0.0203 \\
(-0.760)\end{array}$ \\
\hline \multicolumn{2}{|r|}{ 定 数 } & $\begin{array}{c}-0.200 \\
(-0.302) \\
\end{array}$ & $\begin{array}{l}-0.257 \\
(-1.61)\end{array}$ & $\begin{array}{l}-0.124 \\
(-2.45)\end{array}$ \\
\hline \multicolumn{2}{|r|}{ 重相関倸数 } & 0.823 & 0.809 & 0.878 \\
\hline \multicolumn{2}{|r|}{ サンプル数 } & \multicolumn{3}{|c|}{23} \\
\hline
\end{tabular}

* エントロピーについては, ジョイン值と同様に土地利用 を都市的土地利用 $u$ と自然的土地利用 $n$ の 2 種に区分し 以下のように算定した。

$$
\text { Entropy }=-\sum_{i} p_{i} \ln p_{i} \quad, \quad i=u, n
$$

ここに, pi は地域における自然系, 都市系おのおの土地 利用比率である。

**マニラ首都圈においては,トリップ数単位で全手段の $39 \%$ (PCU 単位では 20\%) を占める道路系公共交通ジプ ニーが幹線道路を連行している. 表中の幹線道路密度は, 自家用車の利便性よりもむしろ道路系公共交通の利便性 を表す指標となっている.

然的土地利用の混在度に基づき算定されるジョイン值 指標は, コンパクト市街地とスプロール市街地との違い を表現し, また両者での自動車保有率の違いを表すも の上位置付けられよう.

\section{（2）都市構造要因を考慮した自動車保有のモデル化}

以上の所得, 都市構造要因を用い自動車保有率の モデル化を試みる. 所得要因としては自動車保有率と

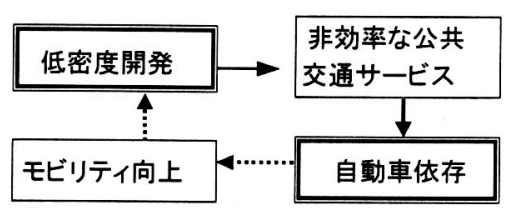

図-10 低密度開発と自動車依存の因果関係

の間に高い相関関係が見られた中高所得世帯比率を 用いる. また, 都市構造要因については, 既往研究に 研究において人口密度指標と自動車依存度との間の 相関関係が示されており, 図一10に示寸因果関倸が 存在するものと考えられる. 本論では密度指標に加え, より局所的な土地利用指標として, スプロールの程度 を表すジョイン值, および土地利用の多様性を表すエ ントロピーについても検討を行う。

表一2 は, 自動車保有率の地域格差を重回帰モデ ルによって表現したものであり, Model-1 から Model-3 は空間構造要因の違いを反映している.いずれのモデ ルの重相関係数も 0.8 を超えており, 現況再現性は良 好である. 空間構造要因については, ジョイン值のパラ メータのみが $1 \%$ 水準で有意となっており,この要因を 用いた Model-3 において最も高い現況再現性が示さ れている. なお, 幹線道路密度については, Model-2 においてのみ十分な有意性が確認されており, Model-3ではほとんど説明力を持たない.

この Model-3 において保有率に対寸る都市構造要 因の寄与を地域別に見ると, 郊外部ではその寄与が大 きく, 中高所得者比率の寄与分の 5 割か 58 割程度に あたることが確認された。このことから，特に郊外部に おけるゾーンレベルでの自動車保有を説明する上で, 都市構造要因としては, 密度のみならず土地利用の連 担性も考慮したジョイン值が有効であるといえる. 


\section{3. モータリリゼーションの郊外化への影響}

\section{（1）郊外化の現状}

図ー9 の左図は, マニラ首都圈の市街化状況を示し たものであり, 1970 年代半ば以降, 急速に市街地が拡 大してきたことが読み取れる. また, 中図は前章で示し たジョイン值を用いて都市的土地利用と自然的土地利 用との混在状況を示したものである.これを見ると，左 図の中心部と近郊部にあたる市街地を除き混在度が 高く, 特に南部の郊外・外延部において著しいスプロ 一ルが展開している状況が伺える。

さらに, 図一9 の右図は, 全世帯に占める 6 千ペソ 月以上の中高所得世帯比率を示したものである. 中図 との対比により, 南部のスプロール市街地には中高所 得世帯の立地增加が影響していることが推察される。

\section{（2）所得階層を考虑した居住立地のモデル化}

マニラ首都圈の低密度開発と自動車依存の因果関 倸を考える際, 中高所得者比率の高さが自動車保有 率の高さに寄与していることが示されたが, スプロール 市街地の形成は単に自家用車の取得可能性の高さだ けでなく, こうした所得層の居住地選択の結果を反映し たものとも考えられる. そこで本研究では, 図一11 に示 すように所得層毎の立地選好, 自動車保有, そして郊 外部での立地優位性との相互関倸に注目してモー夘 ゼーションと郊外化のメカニズムを分析していくこととす る.

このような階層別の立地行動を扱った既往研究とし て, 例えば肥田野ら ${ }^{13}$ はバンコクを対象として先進国 型立地モデルの適用可能性を検討し，所得階層によ る行動パラメータの違いを考慮している. また, $\mathrm{Luk}^{(4)}$ は住宅市場のモデル化において, 所得水準, 一世帯 当りの人数で世帯を分類し, 階層化された世帯の選好 の異質性を考虑して立地選択を表現している.ただし， 簡単な数值シミュレーションの結果を示すにとどまって いる.

本章では，世帯は一定の所得制約および時間制約 の下で, 住居の広さ, 一般財の消費量, 非拘束時間か ら得られる効用を最大化するような居住地選択を行うと 考え,これを以下のようにモデル化する.

$$
\begin{array}{ll}
\max & U^{h}\left(Y_{j i}, G_{j i}, S_{j i}\right) \\
\text { s.t. } & \omega^{h} L^{h}=p Y_{j i}^{h}+r_{i} G_{j i}^{h}+c^{h} T_{j i}{ }^{h} \\
& \Omega=L^{h}+T^{h}{ }_{j i}+S^{h}{ }_{j i}
\end{array}
$$

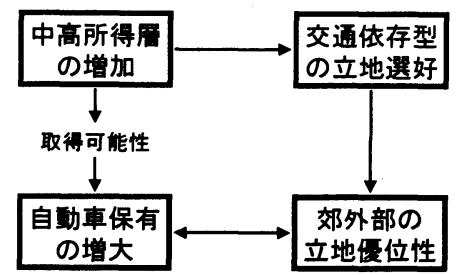

図ー11 モータリゼーションと郊外化のメカニズム

where

$$
\begin{aligned}
& U^{h}\left(Y_{j i}, G_{j i}, S_{j i}\right) \\
& =\left(\beta_{y}^{h}\right) \frac{1}{\sigma^{h}}\left(Y_{j i}^{h}\right)^{\frac{\sigma^{h}-1}{\sigma^{h}}}+\left(\beta_{g}^{h}\right) \frac{1}{\sigma^{h}}\left(G_{j i}^{h}\right)^{\frac{\sigma^{h}-1}{\sigma^{h}}} \\
& \quad+\left(\beta_{s}^{h}\right) \frac{1}{\sigma^{h}}\left(S_{j i}^{h}\right)^{\frac{\sigma^{h}-1}{\sigma^{h}}}
\end{aligned}
$$

ここで, 添字 $j$ は従業地, $i$ は居住地, $h$ は所得階層 を表し, $Y_{j i}$ は従業地 $j$, 居住地 $i$ の世帯の合成財消費 量, $G_{j i}$ は土地消費量, $S_{j i}$ は非拘束時間を表す. また, $\omega^{h}$ は賃金水準, $p$ は合成財価格, $r_{i}$ は地代, $c^{h}$ は単位 時間当たりの交通費用, $T^{h}{ }_{j i}$ は通勤所要時間, $\Omega$ は利 用可能時間, $L$ は労働時間である. $\beta_{i}{ }^{h}, \beta_{g}{ }^{h}, \beta_{s}{ }^{h}$ は分配 パラメータ, $\sigma^{h}$ は消費財間の代替弾力性である.

このモデルでは $\mathrm{Luk}^{14)}$ と同様に CES 型の効用関数 を仮定しており, 所得階層間で行動規範は同一と扱っ ているが, 分配パラメータおよび代替弾力性の相違に よって選好の異質性を表現している.

なお, 式(2)〜式(5)加導出される間接効用関数は 以下の通りであり，以下これを居住効用と呼ぶ.

$$
V_{j i}^{h}=\frac{\left\{\omega^{h}\left(\Omega-T^{h}{ }_{j i}\right)-c^{h} T^{h}{ }_{j i}\right\}^{\frac{\sigma h-1}{\sigma h}}}{\left(\beta_{y}^{h} p^{1-\sigma h}+\beta_{g}^{h} r_{i}^{1-\sigma h}+\beta_{s}^{h} \omega^{h^{1-\sigma h}}\right)^{-\frac{1}{\sigma h}}}
$$

式(6)における通勤世帯の居住効用のパラメー夕推 定結果を表ー3 に示す.この結果より，例えば消費財 間の代替弾力性は高所得者層ほど高い傾向が伺える. 推定にあたっては, 1996 年のパートントリップ調査 (Metro Manila Urban Transportation Integration Study: MMUTIS) ${ }^{15)}$ における通勤 OD データおよび家庭所得 調查(Family Income and Expenditure Survey:FIES) ${ }^{16)}$ における世帯所得データを用いた.

\section{（3）交通条件の居住立地優位性への影響}

式(6)に基づき, 交通所要時間の居住効用への影響度は 弾力性指標で次式のように表せる.

$$
\frac{\partial V_{j i}^{h} / V_{j i}^{h}}{\partial T^{h}{ }_{j i} / T^{h}{ }_{j i}}=-\frac{\sigma^{h}-1}{\sigma^{h}} \cdot \frac{1}{\frac{\Omega}{T^{h}{ }_{j i}\left(1+c^{h} / \omega^{h}\right)^{-1}}}
$$


表ー3 通勤世帯の居住効用パラメータの推定結果

\begin{tabular}{|c|c|c|c|}
\hline パラメータ & 低所得層 & 中所得層 & 高所得層 \\
\hline$\sigma^{h}$ & 1.09 & 1.62 & 1.74 \\
$\beta_{y}{ }^{h}$ & 0.322 & 0.647 & 0.532 \\
$\beta_{g}{ }^{h}$ & 0.112 & 0.156 & 0.156 \\
$\beta_{s}{ }^{h}$ & 0.566 & 0.197 & 0.312 \\
\hline 重相関係数 & 0.918 & 0.830 & 0.558 \\
\hline サンプル数 & \multicolumn{3}{|c|}{1849} \\
\hline
\end{tabular}

推定モデル $\quad P_{j i}^{h}=\exp \left(V_{j i}^{h}\right) / \sum_{i} \exp \left(V_{j i}^{h}\right)$

ここに, $P_{j i}^{h}$ は徙業地を $j$ にも所得階層 $h$ の通勤世帯 が居住地として地域 $i$ を選択する確率である.

式(7)の右辺より, 交通所要時間が短いほど居住効用 が増すことが示されるが，単位時間当りの交通費用 $c^{h}$ が貨金率 $\omega^{h}$ と等しいと仮定すれば, 所得階層間での 交通所要時間の影響度 (弹力性)の違いは, 所得階層 間での消費財間の代替弾力性のみを反映していること がわかる. また, 表一3 における消費財間の代替弾力 性 $\sigma^{h}$ の值を用いれば, 高所得者層ほど居住効用にお ける交通所要時間の影響度が大きいことが推察される。 これらの結果と図ー12 に示す自動車交通によるアクセ シビリティの優位性とを対比させれば, 図ー9(右)に示 した中高所得世帯の郊外立地がモータリゼーションに 起因したものであることが容易に伺える.

\section{4. 市街地形成の空間モデル}

\section{(1)市街地形成における集積効果と混在効果の抽出}

スプロール化現象は, 都市空間の拡大に伴う都市的 土地利用と自然的土地利用との混在に起因したもので あり, その混在状態が秩序性を欠くとき, 同時に都市活 動や資源配分の効率性が損なわれる. 都市計画に基 づく土地利用規制や交通施設等の適切な配置は, 都 市活動に一定の集積効果を付与し, 秩序性や効率性 の維持に資すると期待される. しかしながら, 多くの途 上国大都市においては,こうした仕組みが未整備なま まに集積効果の働かないスプロール市街地が拡大す るとの状況が見られる. マニラ首都圈の郊外市街地は まさに, その様相を呈している. 都市計画的な裏づけ のない民間開発地(subdivision development)は, 最低 限の域内道路網と小規模なパラトランジット・サービスし か備えておらず, 結果として自動車交通に依存した非 効率な市街地が拡大している.

土地利用の集合的な秩序形成をモデル化したもの として, 自己組織化アプローチを用いた Whiteら ${ }^{17)}$

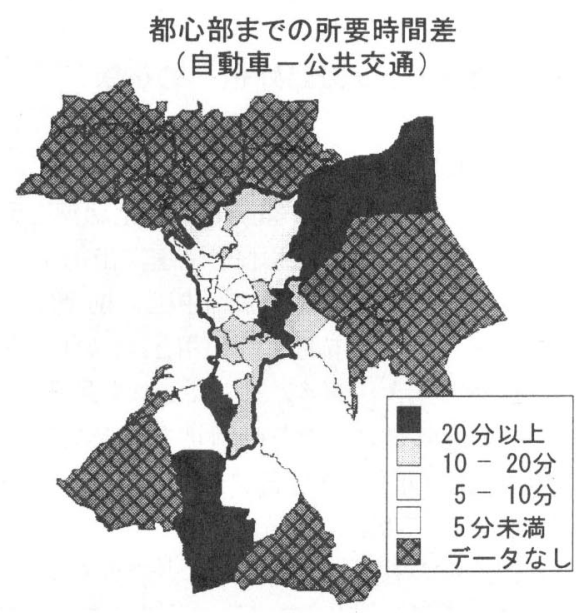

図ー12 自動車交通によるアクセシビリティの優位性

の研究がある. そこでは, 住宅用途, 商業用途, 工業 用途, 及び交通施設等の空閒的な相互作用を，セル ラーオートマタ(CA) モデルにより表現している. また, オハイオ州シンシナティでの適用例に基づき, CA を用 いたミクロ土地利用モデルの計画支援ツールとしての 有用性を示している.ただし，分析対象は都市的土地 利用のみに限定される. $\mathrm{Xie}^{18)}$ は都市力学進化モデル に基づいた一般化モデルを構築し，土地利用が構造 化される過程や既存の都市活動が新規活動の配置を どのように決定するかを示している.

本研究では, White ${ }^{17)}$ の手法を, 自然的土地利用 との混在を含む郊外市街地一と適用し，集積効果に基 づく土地利用の秩序形成を以下のように表わす。 Whiteによれば, 括弧内は主体 $k$ の立地ポテンシャルと 定義される.

$$
L U_{m}=\arg \max _{k}\left(\sum_{l} u^{\prime, k} A_{j(m)}^{\prime}+U^{k} k \in K\right)
$$

本研究ではこれを, 第 1 項の局地的ポテンシャルと 第 2 項の広域的ポテンシャルの和として表現している. 局地的ポテンシャルとは, 近隣土地利用との空間的相 互作用により説明される項であり，広域的ポテンシャル とは, 地域(ゾーン)の立地需要量により説明される項 である.ここに, $L U_{m}$ は空間 $m$ の土地利用用途であり, 第 1 項は周辺空間 $j(m)$ における各種用途 $l$. の集積量 $A_{j(m)}{ }^{\prime}$ と用途間の影響度 $u^{l, k}$ に依存して決定されるとい うメカニズムを表している. $u^{l, k}$ は用途 $l$ の用途 $k$ への影 響度であり，同種用途間 $(l=k)$ の影響度が大きい場合 には土地利用は純化されたパターンを示し, 異種用途 間 $(l \neq k)$ の影響度が大きいほど混在したパターンを示 すことになる. その意味で, 同種用途間の影響度は各 用途の集積効果の大きさを表し, 異種用途間の影響 
表 -4 用途間影響度に関する推定結果

\begin{tabular}{|l|l|r|r|r|r|}
\hline \multicolumn{2}{|c|}{} & 中心部 & 近郊部 & 郊外部 & 外延部 \\
\hline \multirow{4}{*}{ 住 } & 住宅地 & 0.946 & 0.426 & 0.309 & 0.385 \\
宅 & 商業地 & -0.184 & -0.145 & -0.195 & -0.153 \\
地 & 農地・緑地 & -0.273 & -0.006 & 0.015 & -0.122 \\
& 隣接道路 & -0.188 & 0.011 & 0.063 & 0.252 \\
& 周辺道路 & -0.154 & 0.155 & 0.144 & 0.220 \\
\hline \multirow{4}{*}{ 商 } & 住宅地 & 0.479 & -0.001 & -0.148 & -0.061 \\
業 & 商業地 & 0.317 & 0.460 & 0.704 & 0.664 \\
地 & 農地・緑地 & -0.445 & -0.110 & -0.110 & -0.180 \\
& 隣接道路 & -0.023 & 0.169 & 0.165 & 0.288 \\
& 周辺道路 & -0.207 & 0.135 & 0.150 & 0.233 \\
\hline & 相関係数 & 0.778 & 0.827 & 0.822 & 0.943 \\
& サンプル数 & 1765 & 2069 & 1320 & 1344 \\
\hline
\end{tabular}

度は混在効果の大きさを表わすものである.

マニラ首都圈の郊外化にともなう土地利用の混在化 の原因を, 用途間の影響度から解釈するために, 式 (8)の立地ポテンシャルの確率変動を考慮した次式の ロジットモデルに基づきパラメータ $u^{l, k}$ の推定を試みた. ここに, $P_{m}^{k}$ は空間 $m$ に用途 $k$ の土地利用が出現する 確率である.

$$
P_{m}^{k}=\frac{\exp \left(\sum_{l} u^{l, k} A_{j(m)}^{l}+U^{k}\right)}{\sum_{k^{\prime}} \exp \left(\sum_{l} u^{l, k^{\prime}} A_{j(m)}^{l}+U^{k^{\prime}}\right)}
$$

上式における，マニラ首都圈の土地利用形成にお ける用途間影響度の推定を行った.ここでは, 土地利 用用途を住宅地, 商業・業務地, 農地・緑地および道 路と区分し,それぞれの総量はゾーンごとに与えられ

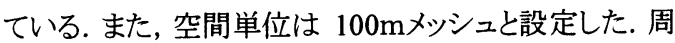
辺土地利用の影響については, 幾つかの距離帯を設 定してそれぞれの土地利用の影響を見たが，説明力 の高さから隣接する 8 メッシュの用途の影響のみを考 慮した. 一方, 道路の影響については, 隣接メッシュの みならず, その外周のメッシュからの影響を考虑した。 なお, 本論文では $U^{k}$ は定数パラメータとして同時推定 している.

表一 4 は, 最尤法による用途間影響度の推定値を首 都圏内の地域別に示したものである. 住宅地, 商業・ 業務地ともに同種の用途間で正の影響が働き,一定の 集積効果が働いていることが読み取れる. しかしながら, 住宅地に関しては中心部から郊外部に向けて集積効 果が低減するという傾向が読み取れる. 商業・業務地 については, むしろ郊外部において集積効果が高いと の傾向が見られるが，これは大規模小売店舗の郊外 展開等にも起因しているものと考えられる.

図ー13 および図ー14 は, 表-3 から住宅地相互の 影響度と道路の住宅地への影響度を取り出して, 地域
別の值を比較したものである. これより，先に述べたよう に郊外部に向けて, 住宅地の集積効果が低減する一 方で道路の誘導効果が高まるというリボン状開発の傾 向が顕著に見られる.

\section{(2)ミクロ土地利用モデルによる市街地拡大の予測}

ここではゾーンの人ロをコントロールトータルとしてミ クロな土地利用配置の決定をモデル化する. 家計, 企 業, 農家という3つの土地利用主体を取り上げ, 各主体 $k$ の人口を $D^{k}$, 一人当りの土地需要面積を $a^{k}$ とすれ ば, 式(9)は以下の条件を満たすことになる。

$$
\sum_{m \in M} a^{k}\left(\frac{\exp \left(\sum_{l} u^{l, k} A_{j(m)}^{k}+U^{k}\right)}{\sum_{k^{\prime}} \exp \left(\sum_{l} u^{l, k^{\prime}} A_{j(m)}^{k^{\prime}}+U^{k^{\prime}}\right)}\right)=D^{k}
$$

ここに, $M$ は地域のメッシュ集合であり,立地競合の結 果, 家計, 企業, 農家のいずれかの主体が各々のメッ シュ $m$ を占有するものと考える. メッシュ単位での土地 利用モデルは, 式(10)を満たす需要ポテンシャル $U^{k}$ の決定を下位問題[1]とした2段階のモデルとして次の ように与えられる. これはアロンゾ型の空間均衡モデル としても再解釈される ${ }^{[1]}$

$$
L U_{m}=\arg \max _{k}\left(\sum_{l} u^{\prime, k} A_{j(m)}^{\prime}+U^{k} k \in K\right)
$$

s.t. $\quad \min _{U^{k}} Z^{k}=\sum_{m} a^{k} \ln \left(\sum_{k} \exp \left(\sum_{l} u^{\prime . k} A_{j(m)}^{k}+U^{k}\right)\right)$

$$
-\sum_{k} D^{k} U^{k}
$$

図一15 は, 1996 年の土地利用を現状 (左図) と式 （11）を用いて推計される将来パターン(右図)を示した ものである. 将来推計においては, ゾーン単位での 1990 年から 95 年の間の人口変化率が 1996 年以降も 維持されると仮定し, 2001 年での活動別人口 $D^{k}$ をえ ている. また, 一人当りの土地需要面積を $a^{k}$ は固定し ている. また, 用途間の影響度については, 1996 年時 点での推定值(表一3 参照)を用いている.

\section{5. 都市化とモータリゼーションの相互作用系の モデル化と政策分析}

\section{(1) 相互作用系のモデル化}

本章では, 自動車保有率との関連性が高い中高所 得者比率とスプロール度およびアクセシビリティを媒介 変数として, 立地・土地利用現象と交通現象との相互 作用系を表現する. 
a)住宅地相互の影響度

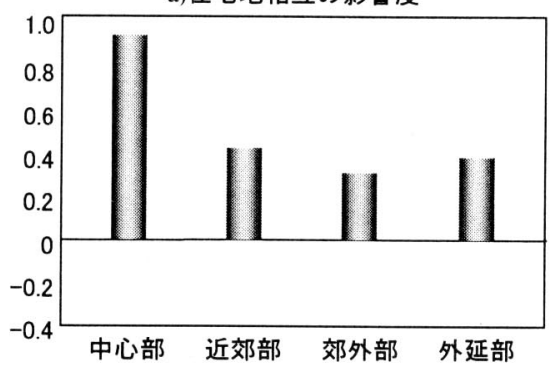

図-13 住宅地の集積効果

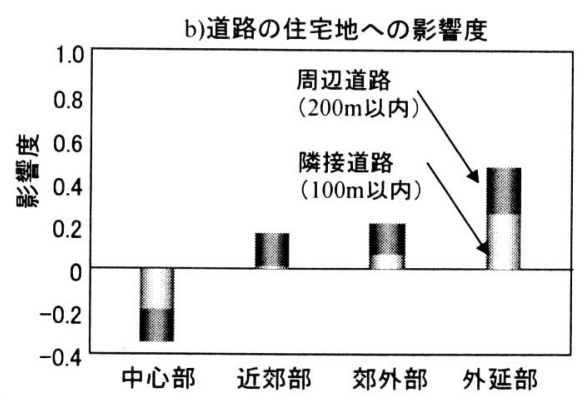

図-14 道路の住宅地誘導効果

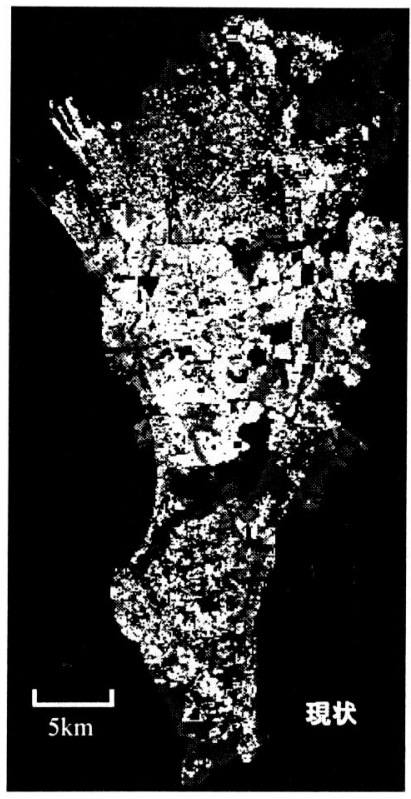

1990 年 1995年の

人口変化率の下での 土地利用変化の予測
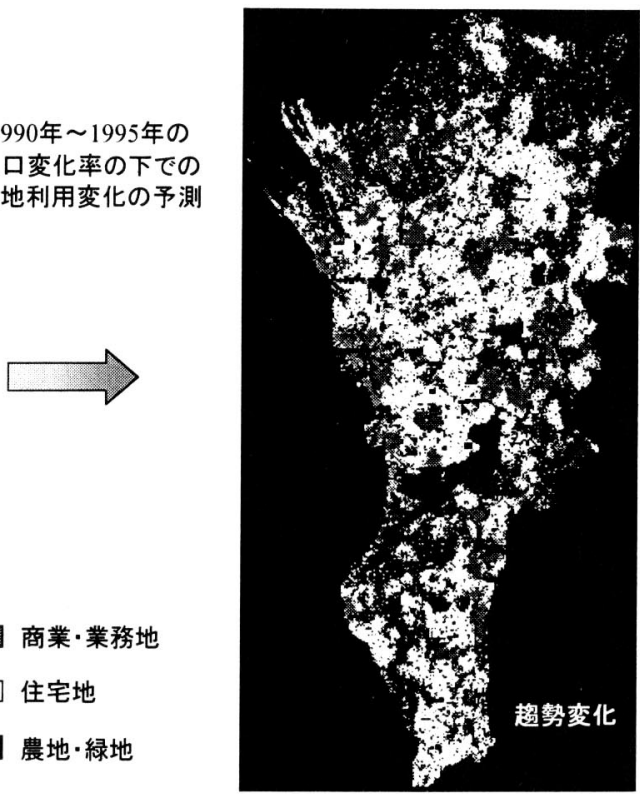

図ー15 ミクロ土地利用モデルによる市街地拡大の予測

図ー16 はモデル化された相互作用系の枠組みを示 したものである. 後の政策分析においては, 主にアクセ シビリティ, 所得および地価の変化を介して政策の効 果が表現される.

図中の各モジュールの構成は以下の通りである. ま ず立地現象は, 3 章で作成した居住立地に企業立地 および土地所有者の行動を加え, 立地分布および通 勤 OD 分布の決定問題としてモデル化している.この 際の基本フレームは応用都市経済モデル (CUE Model ${ }^{19,201}$ に基づいており, これにより価格変化や家 計，企業一の帰属便益を等価的偏差 (Equivalent Variation: EV)で評価することを可能としている. 企業, 土地所有者の行動および市場均衡条件は補注 [2]に 示す通りである.

立地・土地利用モジュールにおいては所得階層別 の通勤OD交通量，およびゾーン別主体別の立地分
布および土地需要量が算定される.この土地需要量を コントロールトータルとして,ゾーン内の $100 \mathrm{mxッシュ}$ 単位での土地利用配置が算定され, 加えて都市的土 地利用 (住宅·商業業務) と自然的土地利用 (農業・自 然) との混在状況がジョイン值指標によって評価され， スプロール度が定量化される。

交通モジュールにおいては, 立地・土地利用モジュ 一ルから出力される各ゾーンの中高所得者比率とジョ イン值から自動車保有率および利用率が求められ, 通 勤ODの情報と併せて都市圈での自動車走行量およ び公共交通の走行量が算定される. これらの出力は政 策評価モジュールにおいて, 大気環境負荷量の算定 のための入力とされると共に, 立地・土地利用モジュー ルへとフィードバックされ, モータリゼーションが都市化 に及ぼす空間的影響が把握される.この際，3章で示 したように, 交通所要時間の居住立地への影響度は所 


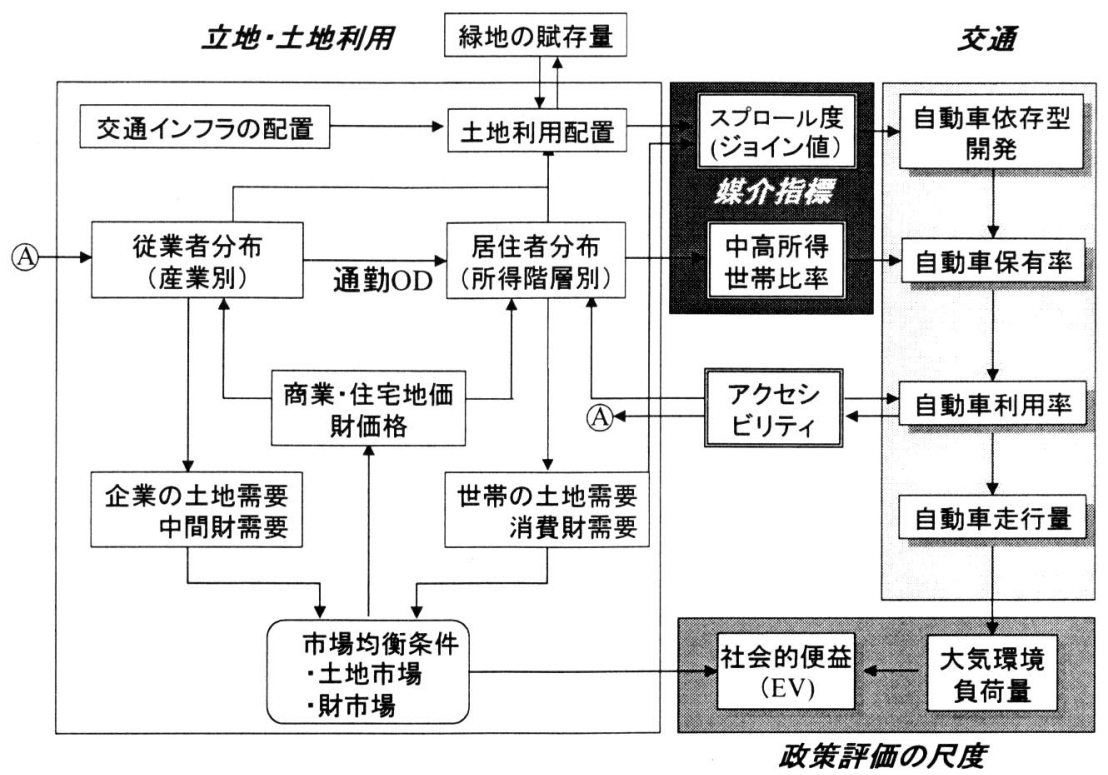

図ー16 立地・土地利用と自動車交通との相互作用系のモデル表現

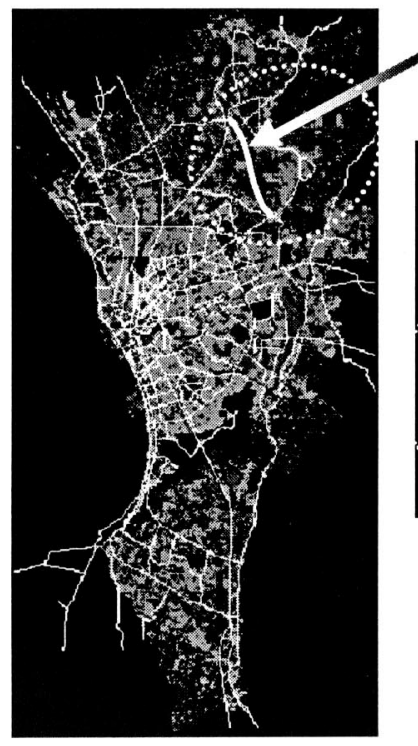

\section{幹線道路の新規整備}

Diliman-Binuksuk : $7.0 \mathrm{~km}$
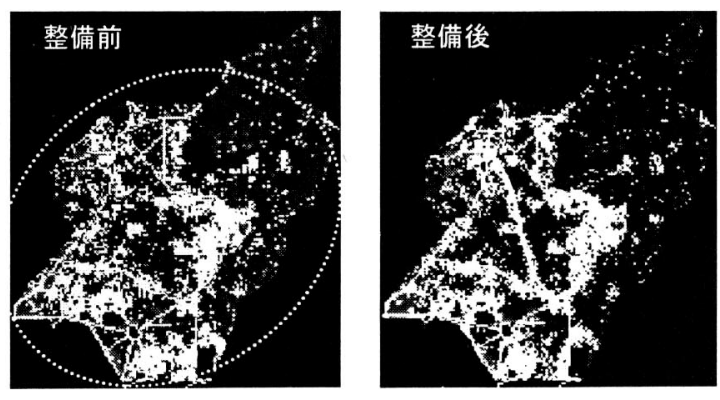

\begin{tabular}{cccc}
\hline & 現 況 & 道路整備後 \\
\hline $\begin{array}{c}\text { スプロール度 } \\
\left(\mathrm{join} / \mathrm{km}^{2}\right)\end{array}$ & $0.449 \longrightarrow 0$ & $\longrightarrow$ & 0.495 \\
\hline $\begin{array}{c}\text { 自動車保有率 } \\
\text { (台/世帯) }\end{array}$ & 0.235 & $\longrightarrow$ & 0.260 \\
\hline
\end{tabular}

図ー17 道路整備に起因した土地利用変化と自動車保有率の変化

得階層毎に異なり, 主として中高所得層の立地分布に 影響が及ぶ。これに伴い，郊外部の居住立地が増加 する場合, 集積効果の低いスプロール市街地が形成さ れることとなる.

\section{(2)相互作用系における道路整備の影響分析}

以上のモデルを用いて, 道路整備に起因した土地 利用変化および自動車保有への影響についての試算
例を図ー17 に示す.ここでは, ケソン市北部における Diliman〜Binuksuk 閒の $7 \mathrm{~km}$ の幹線道路整備を想定 し, 1)アクセシビリティの改善が立地に及ぼす影響(広 域的影響)と 2)道路自体が沿道土地利用に及ぼす影 響(局地的影響)とを考慮している. シミュレーションの 結果, 沿道で帯状の開発が進み, 地域のスプロール度 は0.449から $0.495\left(\mathrm{join} / \mathrm{km}^{2}\right)$ 一と上昇することが示され ている.これに伴う自動車保有率の変化は, 0.235 から 
表ー5 都市・交通政策を例にした政策シナリオ

\begin{tabular}{|c|c|c|c|}
\hline \multicolumn{2}{|r|}{ 施策 } & シナリオ設定 & シナリオの影響 \\
\hline \multirow{4}{*}{$\begin{array}{l}\text { 䚁 } \\
\text { 重 } \\
\text { 抑 } \\
\text { 制 } \\
\text { 政 } \\
\text { 策 }\end{array}$} & 自動車取得税の増徵 & 税率を現行の $34 \%$ から増徴 & \multirow{2}{*}{$\begin{array}{l}\text { 自動車の利用期間に対応 } \\
\text { して可処分所得が減少 }\end{array}$} \\
\hline & 自動車保有税の増徵 & 税額を現行の 1000 ペソ/年から増徵 & \\
\hline & ガソリン税の増徵 & 税額を現行の 4.8 ペソ/1から増徵 & \multirow{2}{*}{$\begin{array}{l}\text { 自動車の利用費用の増加 } \\
\text { による交通量の削減 }\end{array}$} \\
\hline & コードン・プライシング & 都心に流入する自動車交通への課金 & \\
\hline \multicolumn{2}{|c|}{ 軌道系交通 (LRT)の整備 } & $\begin{array}{l}\text { 環状方向の道路交通コリドーEDSA 上に } \\
\text { LRT を整備 (約 } 30 \mathrm{~km} \text { 延長) }\end{array}$ & 交通所要時間の減少 \\
\hline \multirow{2}{*}{$\begin{array}{l}\text { 咅 } \\
\text { 地 } \\
\text { 策 }\end{array}$} & 業務機能の分散 & $\begin{array}{l}2 \text { つの郊外拠点での大規模企業の比率 } \\
\text { が都心部と同程度になるよう業務機能を } \\
\text { 移転 }\end{array}$ & $\begin{array}{l}\text { 郊外拠点での業務部門の } \\
\text { 技術進歩による生産, 雇用 } \\
\text { の増加 }\end{array}$ \\
\hline & 都心立地税 & 都心の立地企業の地代負担を増加 & $\begin{array}{l}\text { 立地費用の増加による企業 } \\
\text { 立地の減少 }\end{array}$ \\
\hline
\end{tabular}

0.260 (台/世帯) への $10 \%$ 程度の増加であり, 道路整備 がモータリゼーションを加速させるという関係が示され ている.

\section{（3）都市·交通政策による相互作用系の制御可能性}

ここでは, 幾つかの都市・交通政策を例として, 相互 作用系の制御可能性を検討する. 対象とする政策は, 表一5 に示す自動車保有・利用の抑制策, 軌道系交 通の整備および立地政策である. また, 政策の評価尺 度として以下の5項目を取り上げる.

(1)自動車保有の抑制

(2)自動車総走行台キ口の抑制

(3)渋滞の著しい都心部一の流入交通量の抑制

(4)居住·従業立地から見た都市構造のコンパク卜性

(5)等価的偏差 $(\mathrm{EV})$ による社会厚生変化

なお, コードン・プライシングや立地政策の対象地域 は, Makati CBD と呼ばれる地域である. CBD 面積は 首都圈の $1 \%$ に過ぎないものの, 自動車トリップ総数の 13\%がここを発着地としている。

自動車取得税や保有税の増徵の影響は自動車の 利用期間に対応した年間所得 $\left(\omega^{h} L\right)$ の減少分として 扱い,ガソリン税の増徵やコードン・プライシングは自動 車の利用費用と考えて利用者の交通時間費用 $\left(c^{h} T j i\right)$ の変化として扱っている.

また, 業務機能の分散は郊外拠点での企業の生産 技術 $\left(P E_{j}^{k}\right)$ の向上により表現し, また都心立地税の影 響は業務地代 $\left(r_{j}\right)$ の増加として扱っている. なお, LRT についてはその運賃を既存の公共交通と同等に設定 している.

これらの政策の影響は図ー16に示した立地・土地利 用モジュール及びアクセシビリティに反映され分析され ることとなる.
まず, 図ー18 は自動車抑制策のうち, 自動車取得 税の増徵とコードン・プライシングの効果を示したもの である.ここで取得税については現行の税率を基準と した増徴率を横軸にとっている. 現状の税率は車両価 格比で 34\%であることから，増徵率 $200 \%$ のケースは 車両価格と同額の税負担を意味する. 一方, コードン・ プライシングは未導入の制度であり, 基準となる現状值 がないことから，取得税の増徵と負担額が同等になるよ うに横軸を設定している.この場合の車両の想定使用 年数は 15 年である. 縦軸の 1.0 は 1996 年時点での現 況を表す。

自動車取得税の増徵については, 保有台数の抑制 に効果が見られるが，増徴率 $200 \%$ ，すなわち取得時 に車両価格に相当する課税を行った場合でも, 保有台 数の減少は $14 \%$ 程度である. さらに総走行台キロの抑 制率は $6 \%$ に過ぎない. なお, 保有台数の減少率と走 行台数の減少率を比較した場合, 後者が小さい結果と なっている.このことは取得税が自動車保有者の実質 所得を減少させ, 地代負担の低い郊外部への立地を 促すことにより, 結果として一人当りの自動車走行距離 が増加することに起因している.

一方, コードン・プライシングの影響を見ると, 課税と 異なり局地的な施策であることから, 首都圈全域での 自動車保有にはほとんど影響しないが, 都心部への流 入台数に対しては一定の削減効果が試算されている. 総走行台キロの抑制については, 取得税の増徵と同 程度の効果が見られる. なお, コードン・プライシングの 影響はそのエリア設定等に依存して変わっていくことが 試算されている.

また, 保有税やガソリン税については, 現行の税額 が低いことから, 増徵率 0〜200\%の範囲では自動車 保有や走行への影響は極めて小さいものであった。 
自動車保有台数

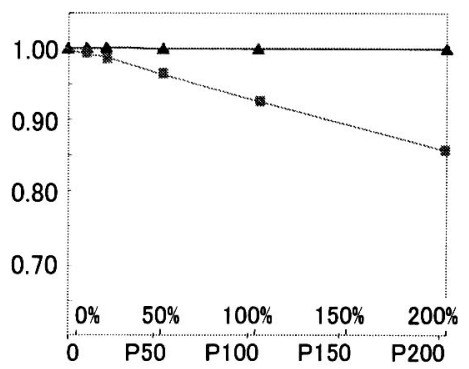

自動車総走行台キロ

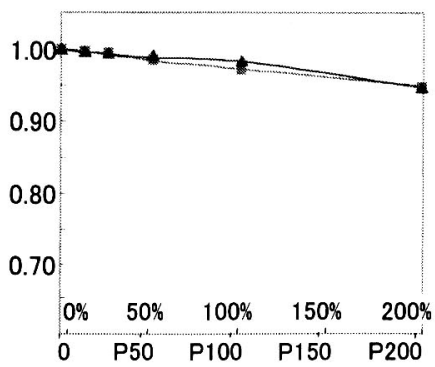

都心流入自動車台数

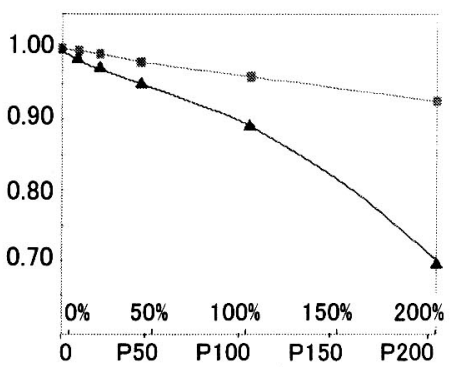

自動車取得税：横軸は增徵率(\%)

——都心流入課金：横軸はペソ $(P)$

図ー18 課税およびプライシング政策の影響

従業者分布の変化

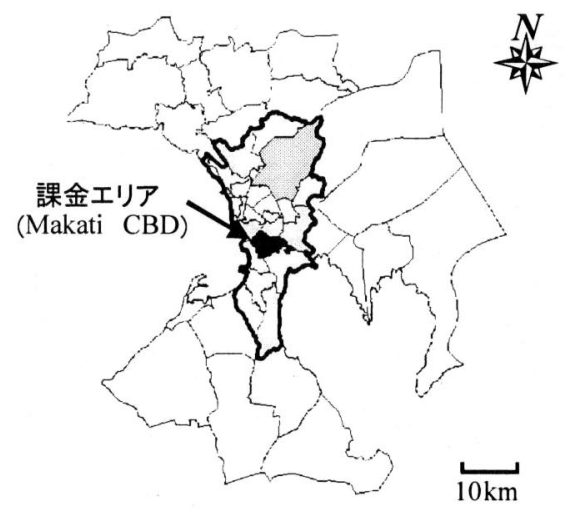

居住者分布の変化

凡例 (単位:千·世帯数)

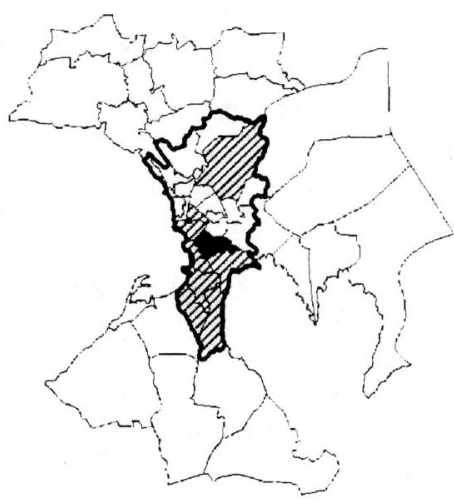

図ー19 コードン・プライシングの立地分布への影響

図ー19 はコードン・プライシングが立地に及ぼす影 響を示したものである.ここでは, 都心部への流入に対 し1回当たり 100 ペソ(約 300 円)を課金した場合の立 地変化を示しており, 従業者分布については課金エリ アでの顕著な減少と, 周辺部での増加が読みとれる. 一方, 居住者分布については, 課金エリアでの中高所 得世帯数の増加と, その周辺部での減少が予測されて いる.ただし, 式 (7)を用いて示したように低所得世帯 の立地にはほとんど影響が及ばない. 中高所得層の 立地に関わる都心方向への回帰と総走行台キロの減 少から, 課金施策により市街地のコンパクト化と職住近 接化が改善されていることが示唆される.

次に自動車抑制策のみならず, 軌道系の交通整備, 都市政策について, その効果を示したものが図－20で ある.ここで, 都心流入課金についてはMakati CBD へ の流入自動車に対し1回当たり 100 ペソを新たに課徴 し，また取得税については現行の税率 $34 \%$ \% 2 倍にするも のである. 車両の使用年数を 15 年程度とすれば, 都心への
マイカ一通勤者の負担は両施策でほぼ同じである. また, 都心立地税については現在の 2 倍の地代負担に相当する 課徴を想定している. LRT 整備及び業務機能分散につい ては，表一5 に示したシナリオを設定している.これらの施 策はその条件設定が異なるため, 值そのものを横並び で比較することはできないが, 各施策の効果を特徵づ けることは可能である. まず, 自動車保有の抑制には 自動車取得税の大幅な増徴のみが有効であり, 郊外 への分散型の立地政策は，逆に保有を促す方向に作 用することが示されている. 一方で, 都心立地税や業 務機能分散策という立地政策は, 流入課金とともに都 心八の流入交通量の抑制に寄与することが読み取れ る. 都市圈全域での走行抑制に対しては, 流入課金, 取得税増徴といった経済的施策は一定の効果をもつ ものの, 立地政策はほとんど寄与していないことが示さ れている.

ここまでは交通指標により政策の評価例を示したが， 次に, 各施策により得られる経済便益, 及び環境改善 


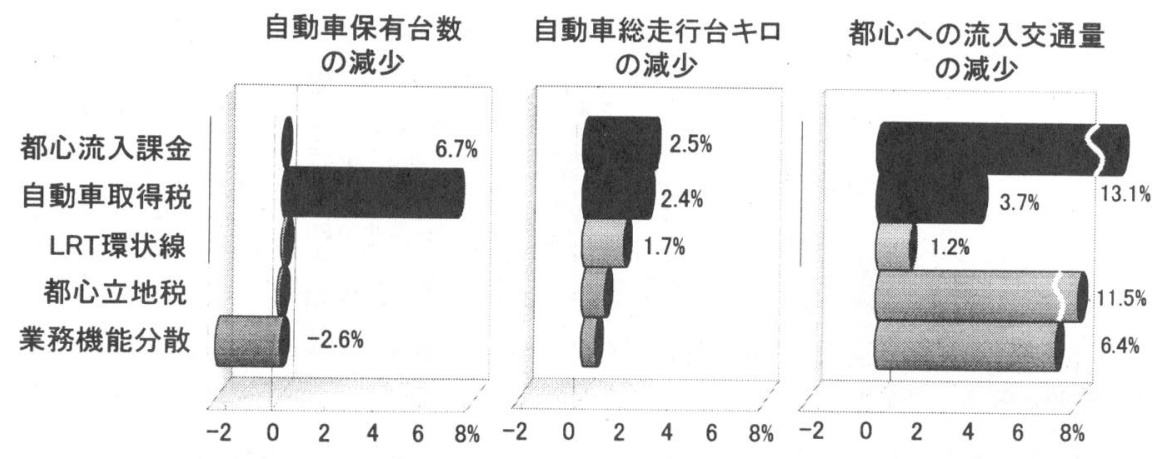

図ー20 経済施策，基盤整備策および立地政策の影響

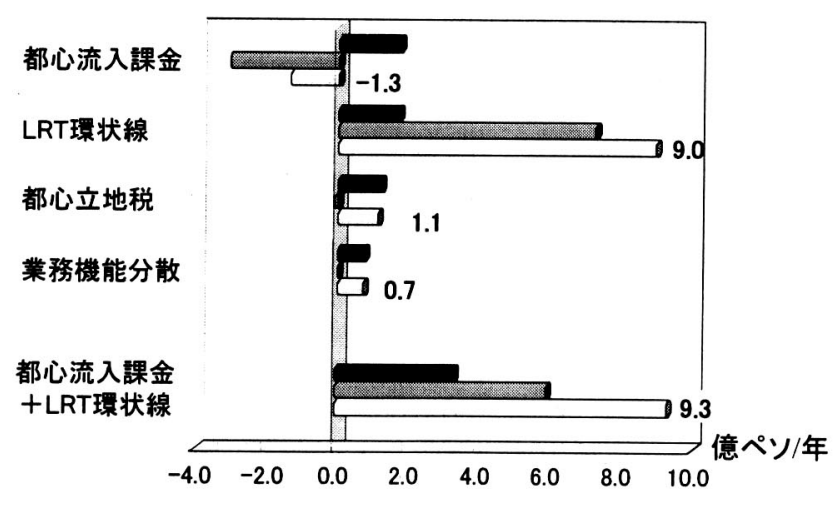

口環境改善便益 経済便益(EV) $\square$ 環境改善便益＋経済便益(EV)

図ー21各施策による経済便益および環境改善便益

便益の推計結果を示したものが図ー21である.ここで, $\mathrm{NOx}, \mathrm{SO}_{2}, \mathrm{PM}$ など交通起源の大気環境負荷による社 会費用の削減量を環境改善便益として評価している. 排出係数については, World Bank の VECP ${ }^{21)}$ を, また 污染の社会的費用については Small and $\mathrm{Kazimi}^{22)}$ 原単位を用いている.

まず, 2種の立地政策は, 若干ながら環境改善便益 をもたらすものの, 経済的便益については極めて限定 的である. 一方, 流入課金策については, 環境改善便 益を上回る経済便益の損失が見られる. LRT整備では 一定の環境改善便益と経済便益をもたらされる. なお, 最下段の「流入課金と LRT 整備の混合政策」に着目 すると, 環境改善便益が大幅に増加し, 総便益につい ても LRT 整備単体のものを上回っている.これにより経 済的施策と交通基盤整備との組み合わせによりバラン スの良い効果がもたらされる可能性があることが示唆さ れる.

\section{6. まとめ}

本研究は, 途上国大都市における自動車交通への 過度の依存がもたらす社会的影響を, 中高所得層の 郊外立地, 市街地のスプロール的拡大, および広域的 な大気環境の悪化等との因果関倸に着目して定量化 したものである. 本研究で得られた知見は以下の通り である.

1)マニラ首都圈における自動車保有の急増が, マクロ 要因として中高所得者層の拡大, 空間的要因として 郊外部の土地利用の混在に起因したものであること を定量的に把握した。

2)所得階層別の居住地選択の分析から, 時間, 空間 に関わる価值意識を抽出し, 所得階層間の交通依 存度の違いを定量化した. その結果, 自動車保有の 増加と中高所得階層の交通依存型の立地選好との 相乗的な作用により, 郊外部の立地優位性が高まる 
ことを確認した.

3)スプロール現象の原因として, 郊外部での市街地の 集積効果の低下, 道路沿いのリボン状開発の進行メ カニズムを明らかにした.

4)政策の影響分析から, 課税やプライシングによる自 動車保有の抑制には非常に厳しい措置を要すること が確認された. さらに, 流入課金等の施策は, それ 単独では社会厚生の低下を招く可能性があること, ただし軌道系交通整備との適切な組み合わせにより, 改善が図られうることを示した。

5)課税やプライシングは, それ単独では自動車利用者 の費用負担增に伴う社会経済的損失を招く可能性 がある.この改善のためには, 税収や課徴金収入を 軌道系交通の整備財源に充当すること等による, 公 共交通整備とのバランスのよい組み合わせが必要で ある.

また, 本研究で開発したモデルについて, 方法論上 の成果を以下にまとめる.

1)ミクロ土地利用モデルと応用都市経済モデルの結合 により, 経済成長や交通改善に伴う将来の市街地拡 大を捉える方法を示した.このことは, Transitoriented Development の検討等において有効な手 法と考えられる.

2)さらに, 土地利用混在度の現状評価にのみ用いられ ていたジョイン法を, ミクロ土地利用モデルと自動車 保有率モデルとのインターフェースとして導入するこ とで, 土地利用-交通モデルのより精緻な枠組みを 提供した.

なお, 本稿では都市化とモータリゼーションとの相互 作用系の制御にかかわる政策評価システムを構筑した ものの，現状ではその基本性能を確認したに過ぎない． 今後, 多時点データによるモデルの時間移転性の確 認, 他の途上国大都市への移転可能性の検討が残さ れている. また, モデル化の観点からは, 異なる空間レ ベルのモデル群のミクロ行動理論に基づく統合, 本稿 では捨象された地域固有の価值観や行動規範の考慮 等が挙げられる.

謝辞: 本研究は, 日本学術振興会の未来開拓学術推 進事業「アジアの環境保全」における研究プロジェクト 「フィリピンにおける大都市地域および地方部の整備, 開発, 保全に関する研究」(代表: 東京工業大学 大町 達夫教授, 平成 9 年度〜)の研究費を利用して実施し たものである. また, 分析にあたっては国際協力事業 団及びフィリピン大学交通研究センターNCTS より MMUTIS のパーソントリップ調査データや土地利用デ 一タを利用させていただいた. 貴重な資料を提供いた だいた関倸各位に謝意を表する.さらに, 研究を進め
るにあたって貴重な助言を頂いた東京工業大学 黒川 洸教授, 屋井鉄雄教授, 上田孝行助教授, 名古屋大 学 林良嗣教授, 及び立地モデルの基本設計に関わ った元大学院生の山野浩氏にも謝意を表する.

\section{補注}

[1] アロンゾ型の空間均衡モデルとの対比でいえば,これ はクローズドシティにおいて都市人口規模を所与としたとき の，効用水準を求めるプロセスとして見なすことができる. 本モデルでは, これを最適化問題として表現している゙32.

[2] 経済主体の行動のモデル化

(1)企業については以下のような利潤最大化行動を仮 定する.

$$
\max \left(p^{k} X_{j}^{k}-\sum_{h} \omega^{k h} L_{j}^{k h}-r_{j} G_{j}^{k}-c^{k} T_{j}^{k}\right)
$$

s.t.

$$
X_{j}^{k}=P E_{j}^{k} \prod_{h}\left(L_{j}^{k h}-T_{j}^{k}\right)^{\alpha\left(L^{k h}\right)}\left(G_{j}^{k}\right)^{\alpha\left(G^{k}\right)} \prod_{h}\left(T_{j}^{k}\right)^{\alpha\left(T^{k}\right)}
$$

ここに, $j$ :従業ゾーンのラベル,$k$ : 業種のラベル, $h$ :所得 階層のラベル, $p^{k}$ :生産財価格, $X_{j}^{k}$ : 企業の生産量, $L_{j}^{k h}$ : 労働投入量, $\omega^{k h}$ : 賃金水準, $G_{j}^{k}$ : 土地投入量, $r_{j}$ : 業務地代, $T_{j}^{k}$ : 業務交通投入量, $c^{k}$ :単位トリップの 費用, $\xi^{k h}$ :業種別 - 所得階層別従業者数, $P E_{j}^{k}$ : 技術 係数 (大規模事業所シェア), $\alpha\left(L^{k h}\right), \alpha\left(G^{k}\right), \alpha\left(T^{k}\right)$ : 分配パラメータ

式(12)と(13)を解くと,以下のような各要素需要及び 間接利潤関数が得られる.

労働

$$
: L_{j}^{k h}=\frac{\alpha\left(L^{h}\right) p^{k} X_{j}^{k}}{\omega^{k h}}+\frac{\alpha\left(T^{k h}\right) p^{k} X_{j}^{k}}{c^{k}+\omega^{k h}}
$$

業務地

$$
\text { : } G_{j}^{k}=\alpha\left(G^{k}\right) p^{k} X_{j}^{k} / r_{j}
$$

業務卜リップ： $T_{j h}^{k}=\alpha\left(T^{k}\right) p^{k} X_{j}^{k} /\left(c^{k}+\omega^{k h}\right)$

間接利潤関数:

$$
\begin{aligned}
& \begin{aligned}
\Pi_{j}^{k}=(1 & \left.-s^{k}\right)\left\{p^{k} P E_{j}^{k} \cdot \prod_{h}\left(\alpha\left(L^{k h}\right) / \omega^{k h}\right)^{\alpha\left(L^{k h}\right)}\right. \\
& \left.\times\left(\alpha\left(G^{k}\right) / r_{j}\right)^{\alpha\left(G^{k}\right)}\left(\alpha\left(T^{k h}\right) / \omega^{k}\right)^{\alpha\left(T^{k h}\right)}\right\}^{\frac{1}{1-s^{k}}}
\end{aligned} \\
& \text { where } \quad s^{k}=\sum_{h} \alpha\left(L^{k h}\right)+\alpha\left(G^{k}\right)+\sum_{h} \alpha\left(T^{k}\right)
\end{aligned}
$$


企業の立地選択確率 $: P_{j}^{k}=\frac{\exp \left(\theta^{k} \Pi_{j}^{k}\right)}{\sum_{j^{\prime}} \exp \left(\theta^{k} \Pi_{j^{\prime}}^{k}\right)}$

所得階層別の従業者数 $: L_{j}^{k h}=\xi^{k h} \cdot P_{j}^{k}$

(2)不在地主については以下のような利潤最大化行動 を仮定する.

$\max \left(\left\{r_{H i}\left(G_{H i}\right)^{-\rho}+r_{K i}\left(G_{K i}\right)^{-\rho}+r_{F i}\left(G_{F i}\right)^{-\rho}\right\}^{-\frac{1}{\rho}}\right)$

s. t. $G_{H i}+G_{K i}+G_{F i}=G_{i}$

ここに, $r^{H}$ : 住宅地代, $r^{K}$ :業務地代, $r^{F}$ : 農業地代 $G^{H}$ : 住宅地供給面積, $G^{K}{ }_{i}$ : 業務地供給面積 $G^{F}$ :農地供給面積, $\rho$ :パラメータ

住宅地供給面積: $G_{i}^{H}=\left\{\left(r_{H i}\right) \frac{1}{1+\rho} / S\right\} G_{i}$

業務地供給面積: $G_{i}^{K}=\left\{\left(r_{K i}\right)^{\frac{1}{1+\rho}} / S\right\} G_{i}$

農業地供給面積: $G_{i}^{F}=\left\{\left(r_{F i}\right)^{\frac{1}{1+\rho}} / S\right\} G_{i}$

where $S=\left(r_{i}^{H}\right)^{\frac{1}{1+\rho}}+\left(r_{i}^{K}\right)^{\frac{1}{1+\rho}}+\left(r_{i}^{F}\right)^{\frac{1}{1+\rho}}$

(3)市場均衡条件

合成財市場 $\quad: \sum_{i} \sum_{j} L_{j i}^{h} Y_{j i}^{h}=\sum_{j} \sum_{k} X_{j}^{k}$

住宅土地市場 : $G_{i}^{H}=\sum_{h} \sum_{j} L_{j i}^{h} G_{j i}^{h}$

業務土地市場 : $G_{i}^{K}=\sum_{k} G_{i}^{k}$

ここで, $L_{j i}{ }^{h}$ は従業地 $j$ 及び居住地 $i$ を選択する所得階層 $h$ の世帯数で,間接効用 $V_{j i}^{h k}$ 用いたロジットモデルにより以 下のように求められる.

$$
L_{j i}^{h}=\sum_{k}\left(\left(\exp \left(V_{j i}^{h k^{\prime}}\right) / \sum_{k^{\prime}} \exp \left(V_{j i}^{h k^{\prime}}\right)\right) \cdot L_{j}^{k h}\right)
$$

\section{参考文献}

1) Kenworthy, J.R. and Laube, F.B.: Patterns of automobile dependence in cities: an international overview of key physical and economic dimensions with some implications for urban policy, Transportation Research part A, Vol.33. pp.691-723. 1999.

2) Gakenheimer. R.: Urban mobility in the developing world. Transportation Research Part A. Vol.33. pp.671-689, 1999.

3）林良嗣,富田安夫.土井健司.スパラットリチカ.加藤博和: 都市交通によるエネルギー消費およびその環境負荷へ の影響に関する比較.土木計画学研究・講演集 No.15.pp.939-944.1992.

4）林良嗣,中澤菜穂子、スパラットリチカ:バンコクと東京の 比較に基づく都市インフラ整備と環境負荷の分析, 第 28 回日本都市計画学会学術論文集.pp.427-432, 1993.

5) Y. Hayashi, R. Suparat, R. Mackett, K. Doi, Y. Tomita, N. Nakazawa, H. Kato and K. Anurak: Urbanization, Motorization and the Environment Nexus-A International Comparative Study of London, Tokyo, Nagoya and Bangkok-, Memoirs of School of Engineering, Nagoya University, Vol.46, No.1, pp.55-97. 1995.

6) 加藤博和, 林良嗣, 丸田浩史: モータリゼーション進展過 程を考慮した都市旅客交通起源 $\mathrm{CO}_{2}$ の長期的分析手法, 土木計画学研究·講演集, No.22(2), pp.563-566, 1999.

7) 土井健司, 紀伊雅敦, フセイン・リダサン:発展途上国の 通勤・通学問題の構造一マニラ首都圈を対象として一, IATSS Review. Vol.25. No.3. pp.205-212. 2000.

8) 高見淳史, 室町泰徳, 原田昇, 太田勝敏：自動車利用 削減のための土地利用／交通施策に関する議論の整理, 土木計画学研究·講演集, No.20(2). pp.153-156. 1997.

9) 芦沢哲蔵: 自動車保有率と都市構造との関係について の研究, 日本都市計画学会学術研究論文集.No.24, pp.259-264, 1989.

10) 加藤博和, 林良嗣: 経済成長レベルと都市構造要因を 考慮した乗用車保有水準の分析とモデル化, 交通工学, Vol. 32. No.5, pp.41-50, 1997.

11) 青島縮次郎.駱柄璋.金井昌信.小野ももこ.古澤浩司: 地 方都市圈における郊外居住化とモータリゼーション進展 に関する関連分析. 土木計画学研究·講演集 No.22(2). pp.583-586.1999.

12）恒川篤史, 李東根, 米林聡, 井手久登:土地利用混在の 定量化手法, 情報環境科学, Vol.20-2, pp.115-120, 1991.

13) 肥田野登, 中村英夫, 吉江勝広, サマート・ラチャポンシ 卡, 福田敦:土地利用交通モデルの開発途上国への適 用, 土木計画学研究·講演集, No. 6. pp.141-147. 1984.

14) Luk, F.K.: A general equilibrium simulation model of housing markets with indivisibility. Regional Science and Urban Economics. Vol.23, pp.153-169. 1993.

15) MMUTIS STUDY TEAM: Draft Final Report. Metro Manila Urban Transportation Integration Study, 1998.

16) National Statistics Office: Annual Report of Family Income and Expenditure Survey, 1998.

17) White, R., Engelen, G. and Uljee. I.: The use of constrained cellular automata for high-resolution 
modeling of urban land-use dynamics, Environment and Planning B: Planning and Design, Vol.24, pp.323-343, 1997.

18) Xie, Y.: A general model for cellular urban dynamics, Geographical Analysis, Vol.28, pp. 350-373, 1996.

19）金広文, 山野浩, 土井健司:ミクロ行動論に基づく都市圈 大規模計量モデルの開発とマニラ首都圈への適用,土木 計画学研究·講演集 No.23(2), pp.501-504, 2000.

20) 武藤真一, 上田孝行, 高木朗義, 富田貴弘: 応用都市経済 モデルによる立地変化を考慮した便益評価に関する研 究, 土木計画学研究·論文集 No.17, pp.257-266, 2000.

21) Larssen, S., Gram. F.. Hagen, L.O., Jansen, H., Olsthoorn. X., Lesaca, R., Anglo, E., Torres, E.B., Subida, R.D. and
Fransisco, H.A.: Urban air quality management strategy in Asia: Metro Manila Report. World Bank Technical Paper No. 380. 1997.

22) Small, K.A. and Kazimi, C.: On the costs of air pollution from motor vehicles, Journal of Transport Economics and Policy, Vol.29, pp.7-32, 1995.

23) 紀伊雅敦, 土井健司: 途上国大都市を対象とした交通計 画支援のためのミクロ土地利用モデル,土木計画学研 究·講演集 No.23(2),pp.505-508. 2000.

\title{
A MODEL ANALYSIS ON CONTROLLABILITY OF SYNERGETIC SYSTEM BETWEEN SUBURBANIZATION AND MOTORIZATION IN THE METRO MANILA
}

\author{
Kenji DOI, Masanobu KII, Kwangmun KIM and Sheilah A. GAABUCAYAN
}

In this study, motorization problems in developing metropolises are considered as the negative feedback effect of economic growth, urban expansion, and automobile dependence. The purpose of this study is to capture the relationship of these three factors and to develop the evaluation system of the manageability of motorization. Urban activity location of each income class household, urban sprawl expansion and their influence on automobile dependence are modeled consistently. Based on these models, urban-transportation analysis system representing the interaction of economical behavior, land use and automobile dependence is constructed. This system is adopted to evaluate automobile-related taxation, pricing, provision of LRT and polycentric urban policies for Metro Manila. 